\title{
Microscopic and Chemical Characterization of Flour of Fruits: An Alternative Source for Supplemental Feeding
}

Ana Maria Pinto dos Santos ${ }^{1 *}$, Rosemary Duarte Sales Carvalho ${ }^{2}$, Ademir Evangelista do Vale ${ }^{2}$, Jeane Santos Lima ${ }^{2}$, Ivanice Ferreira Santos ${ }^{1}$, Uenderson Araujo Barbosa ${ }^{1}$, Hilda Costa dos Santos ${ }^{3}$, Clarissa Duarte Sales Carvalho ${ }^{1}$ and Margareth da Silva Ribeiro ${ }^{2}$

${ }^{1}$ Institute of Chemistry, Federal University of Bahia, Campus de Ondina, 41170-115, Salvador (BA), Brazil

${ }^{2}$ Faculty of Pharmacy, Federal University of Bahia, Rua Barão de Jeremoabo, s / n, 41810-290, Salvador (BA), Brazil

${ }^{3}$ Cetens, Federal University of Reconcavo of Bahia, Av. Centenario, 697, 44085-132, Feira de Santana (BA), Brazil

\begin{abstract}
The present study aimed to characterization microscopic and chemical of four samples of fruit flours: eggplant (Solanum melongena), banana (Musa spp), passion fruit (Passiflora spp) and grape (Vitis vinifera). For the determination of chemical composition acid digestion was via a microwave-assisted using nitric acid and hydrogen peroxide and subsequently analysed by inductively coupled plasma Optical Emission Spectrometry (ICP OES). The validation of method was evaluated by analyzing a certified reference material (CRM), Rice Flour NIST 1568a. The vitamin C contents of the sample flour were determined by the AOAC procedure. The microscopic analyzes were realized with an optical microscope Olympus SZH10 coupled to a digital camera Cannon Power Shot A460. Average mineral concentration in flour samples (in mg/100 g) were: 0.30 to 367 (Ca); 3.38 to $1666(\mathrm{~K}) ; 0.16$ to $216(\mathrm{Mg}) ; 0.023$ to $136(\mathrm{Na}) ; 0.010$ to $9.95(\mathrm{Cu}) ; 0.050$ to $27.87(\mathrm{Fe}) ; 0.052$ to $6.55(\mathrm{Mn}) ; 0,011$ to $6,04(\mathrm{Zn})$ and 2,9 to 70,4 (Vitamin C). The principal component analysis (PCA) showed that the variables vitamin $\mathrm{C}$ and Na have negative correlation with $\mathrm{Mn}$ and these variables contribute to discrimination of samples of banana and passion fruit flour's. Characteristic plant tissue components that compose the fruit flours were observed as well as the irregular addition of starch.
\end{abstract}

Keywords: Flour fruit; Banana; Eggplant; Passion fruit; Grape; Minerals; Histochemical; Microscopic; PCA

\section{Introduction}

Brazil is one of the major producers of fruits worldwide, with an output capacity exceeding forty million tons [1]. In recent years, Brazilian exports of fruits are growing and fruits are getting good value. The supply of tropical fruits almost the whole year round is due to its territorial extension, geographical situation, soil conditions and climate. Many products are made using these fruits through technological process for different purpose, such as fruit's flours. These new products are a viable alternative for nutritional supplementation, especially in developing countries [2].

FAO (2009) estimates that the undernourished population will reach billion of people [3]. Existing functional properties of fruit flours that encourages their consumption. These products should be in accordance with food safety standards, established by national or international legislation. In order to ensure the quality of these new products, there is a need to collect more scientific information including physic-chemical, microbiological, and microscopic properties.

Flour is used in the production processes as raw materials, intermediate or finished products in food industries. The current trend is to replace the wheat flour by other types of grains, seeds, barks and vegetables to produce breads, cakes and pasta products.

Some research has been developed to evaluate the use of fruit in flour replacing or added to flour to improve its nutritional quality particularly in minerals and fibre content [4-6]. The benefits are seeing for either healthy and for those who presents any kind of chronic diseases [7]. As well as to dietary fibers, those products are important sources of vitamins, proteins, minerals, carbohydrates which reduce the risk of many diseases, such as cancer, diabetes, obesity and cardiovascular diseases [8].

As with, the minerals are essential for physiologic functional in the organism and are daily necessary in different quantities of milligrams and micrograms like; copper, iron, manganese and zinc. However, others nutrients like calcium, magnesium, potassium, sodium that also are necessary for life, but are present in higher quantities. Research carried from plant sources of conventional and unconventional demonstrate the existence of significant levels of these nutrients, contemplating the needs of recommended daily intakes [9-12].

However, it's necessary study that allows its safety use, through physical-chemical and nutritional analyses, and also standard parameters of quality. These analyses produce a large amount of data with complex interpretation. In this scenario, chemiometry has proved a useful tool for data analysis. Among the chemometric methods used for exploratory multivariate data analysis, does the Principal Component Analysis (PCA) constitute a technique used to reduce dimensions $[13,14]$.

The objective of this study was to compare the levels of minerals, vitamin $\mathrm{C}$ and morphological characteristics of flour obtained from banana, grape, passion fruit and eggplant commercialized in markets. The mineral composition ( $\mathrm{Ca}, \mathrm{K}, \mathrm{Na}, \mathrm{Mg}, \mathrm{Cu}, \mathrm{Fe}, \mathrm{Mn}$, and $\mathrm{Zn}$ ) was evaluated using statistical tools such as Principal Component Analysis (PCA) which permit to verify the correlation between variables and possible similarities between samples.

*Corresonding author: Ana Maria Pinto dos Santos, Institute of Chemistry Federal University of Bahia, Campus de Ondina, 41170-115, Salvador (BA), Brazil, Fax: +55-71-32836800; E-mail: amps@ufba.br

Received September 03, 2014; Accepted October 22, 2014; Published November 04, 2014

Citation: Santos AMPD, Carvalho RDS, Vale AED, Lima JS, Santos IF, et al (2014) Microscopic and Chemical Characterization of Flour of Fruits: An Alternative Source for Supplemental Feeding. J Food Process Technol 5: 386. doi: 10.4172/2157-7110.1000386

Copyright: (c) 2014 Santos AMPD, et al. This is an open-access article distributed under the terms of the Creative Commons Attribution License, which permits unrestricted use, distribution, and reproduction in any medium, provided the original author and source are credited. 


\section{Materials and Methods}

\section{Instrumentation}

The $\mathrm{Ca}, \mathrm{K}, \mathrm{Mg}, \mathrm{Na}, \mathrm{Cu}, \mathrm{Fe}, \mathrm{Mn}$ and $\mathrm{Zn}$ determination was performed using an ICP OES with an axially viewed configuration (VISTA PRO, Varian, Mulgrave, Australia). The instrumental conditions were: RF generator $(40 \mathrm{MHz})$, power $(1.3 \mathrm{~kW})$, plasma gas flow $\left(15 \mathrm{Lmin}^{-1}\right)$, auxiliary gas flow $\left(1.5 \mathrm{Lmin}^{-1}\right)$, and nebulizer flow $\left(0.7 \mathrm{Lmin}^{-1}\right)$. The optimum conditions for the determination of metals were established using the element manganese to the canal alignment of the spectrometer, as recommended by the manufacturer. The elements and analytical wavelengths were used for quantification: $\mathrm{Ca}$ II $(422.673 \mathrm{~nm}), \mathrm{K}$ I $(766.491 \mathrm{~nm}), \mathrm{Mg}$ II $(285.213 \mathrm{~nm}), \mathrm{Na}$ I (589.592 $\mathrm{nm}), \mathrm{Cu}$ II $(213.598 \mathrm{~nm})$. Fe II $(238.204 \mathrm{~nm}), \mathrm{Mn}$ II $(257.610 \mathrm{~nm})$ and Zn II (334.502 nm). A microwave system (model Start D; Milestone, Sorisole, 67 Italy) equipped with Teflon TFM vessels was used for the digestion of the flour samples.

\section{Materials and reagents}

All water used for the preparation of all samples and solutions is deionized water produced from the Milli-Q system (Millipore, Bedford, MA, USA) with resistivity of $18.2 \mathrm{M} \Omega \mathrm{cm}^{-1}$. Analytical-grade reagents (Merck, Darmstadt, Germany) were used to prepare all solutions and standards. Analytical stock solutions of $1000 \mathrm{mgL}^{-1}$ of each element were used daily to prepare the multielement reference analytical solution. All glassware and polypropylene flasks were washed a neutral detergent, kept in nitric acid bath containing $10 \%(\mathrm{v} / \mathrm{v})$ for at least $12 \mathrm{~h}$ and washed with deionized water before use.

The certified reference material, rice flour NIST 1568 (National Institute of Standards \& Technology, Gaithersburg, MD, USA) was analyzed for validation purpose.

\section{Collection and storage of samples}

Total number of 30 flour samples for the vegetables: eggplant (Solanum melongena), banana (Musa spp), passion fruit (Passiflora $s p p$ ) and grape (Vitis vinifera) were collected from markets of Salvador City, Brazil. The samples had their origin directly identified with the label of the package. Flour samples collected from eleven different manufacturers are distributed and codified as follows: 5, (ED); 1,(FW); 1, (MT); 1(NO); 3, (NL); 3, (NE); 1, (ST); 3, (TN); 2,(VB) ; 5, (VN) ; 5 , (VV). Upon collection, all samples (100 g e $200 \mathrm{~g})$ were stored in desiccators for later analysis.

\section{Chemical analyses}

Minerals: Samples were previously homogenized in their own packing before sampling. Then, $200 \mathrm{mg}$ of each sample was digested via a microwave-assisted procedure. Four $\mathrm{mL}$ of ultrapure water, acid $\mathrm{HNO}_{3} 65 \%(\mathrm{w} / \mathrm{w})(3 \mathrm{~mL})$ and $1 \mathrm{~mL}$ of $\mathrm{H}_{2} \mathrm{O}_{2}(30 \% \mathrm{w} / \mathrm{w})$ in TFM closed vessels were used for the digestion. The mixture was subjected to a digestion program described. The heating program was made according the following stages: (1) power of $600 \mathrm{w}$, temperature ramp time of $5 \mathrm{~min}$, temperature of $80^{\circ} \mathrm{C}$; (2) temperature and power were kept in $2 \mathrm{~min}$; (3) power of $800 \mathrm{w}$, temperature of $120^{\circ} \mathrm{C}$ for $4 \mathrm{~min}$; (4) temperature and power were kept in $2 \mathrm{~min}$; (5) power of $1000 \mathrm{w}$, temperature $180^{\circ} \mathrm{C}$ in $5 \mathrm{~min}$; (6) power of $1000 \mathrm{w}$, temperature $180^{\circ} \mathrm{C}$ in $15 \mathrm{~min}$. After the end of the heating program, the flasks were cooled to room temperature and carefully opened. After digestion, the solutions were transferred to centrifuge tubes of $15 \mathrm{~mL}$, and then, the volume adjusted to $10.0 \mathrm{~mL}$ with ultrapure water. The analytes $(\mathrm{Ca}, \mathrm{K}, \mathrm{Mg}, \mathrm{Na}$, $\mathrm{Cu}, \mathrm{Fe}, \mathrm{Mn}$ and $\mathrm{Zn}$ ) in the final solution were determined by ICP OES.
All assays were conducted in triplicate.

Vitamina C: Vitamin C contents of the sample flour were determined by the AOAC (Método AOAC 967,21) procedure [15], which employed the principle that the ascorbic acid reduces the oxidation-reduction indicator dye, 2,6 dichloro indophenol.

Accuracy: The accuracy was validated by analyzing a certified reference material (CRM), Rice Flour NIST 1568a. Digestion of this material was carried out with the same procedure used for the decomposition flour samples banana, eggplant, passion fruit and grape.

Histochemical and microscopic analyzes: The slides were mounted with the appropriate reagents and visualized with an optical microscope Olympus SZH10 (Shibuya - Ku, Tokyo, Japan) coupled to a digital camera Cannon Power Shot A460. After analyzing the results of the slide collection were recorded by photographs.

\section{Results and Discussion}

\section{Chemical analysis}

The average concentrations \pm standard deviation $(s d)$ of the elements and Vit C in $\mathrm{mg} / 100 \mathrm{~g}$ were calculated for thirty flour samples from different origins are in Table 1 . The samples generally had high levels of macro elements such, potassium, calcium and magnesium. Potassium was the most abundant, recording high levels $(1666 \mathrm{mg} / 100 \mathrm{~g})$ in eggplant (Solanum melongena L.) and lowest (84 $\mathrm{mg} / 100 \mathrm{~g}$ in grape (Vitis vinifera $\mathrm{L}$ ). High potassium values were also found in green banana flour. Thus, some of the difference in the chemical composition of flour is expected. Some of the factors that may be attached to the matrix type, climate, and nature of soil. Compared with the usual mineral values for labels available on the market [14], the levels determined in this study show superior results, indicating the importance of flour as nutrient sources.

\section{Validation of the method}

The accuracy of the method for the determination of elements was validated by analyzing certified reference material (CRM), Rice Flour NIST 1568a. Table 2 shows that the determined values were consistent with the certified values. The paired $t$ test at a $95 \%$ confidence level showed that there was no significant difference between the means of the certified and determined values for most analytes under investigation.

\section{Statistical analysis data analysis}

Equivalent samples were classified by using chemometric methods: Principal Component Analysis (PCA) and Hierarchical Cluster Analysis (HCA) using Stat Soft Statistic version 6. From data sets, $(30 \times 9)$, obtained by the results of triplicate data, flour samples of banana (BA), eggplant (BE), passion fruit $(\mathrm{M})$, grape $(\mathrm{U})$, were set in lines and the concentrations of the analytes were placed in vertical columns. The data was pre-processed by auto-scaled. The two main components of PCA (PC1 e PC2) explain $66.4 \%$ of total variance within the data.

In Figure 1, it is shown the graph of weights, on PC1 all variables are displaced to the region of positive weights of this $\mathrm{PC}$, and then these variables are directly correlated, except vitamin $C$ which is located practically on the center of the axis, which demonstrates its low contribution on this PC. On PC2, the variables vitamin $\mathrm{C}, \mathrm{Na}$, $\mathrm{Ca}$ and $\mathrm{Fe}$ are displaced to the region of positive weights and the variables $\mathrm{Mg}, \mathrm{K}, \mathrm{Mn}, \mathrm{Zn}$ and $\mathrm{Cu}$ to region of negative weights. Being that the variables $\mathrm{Na}$, vitamin $\mathrm{C}$ and $\mathrm{Mn}$ are the largest absolute weights, so are the variables that contribute most 
Citation: Santos AMPD, Carvalho RDS, Vale AED, Lima JS, Santos IF, et al. (2014) Microscopic and Chemical Characterization of Flour of Fruits: An Alternative Source for Supplemental Feeding. J Food Process Technol 5: 386. doi:10.4172/2157-7110.1000386

Page 3 of 6

\begin{tabular}{|c|c|c|c|c|c|c|c|c|c|c|}
\hline & Sample & $\mathrm{Cu}$ & $\mathrm{Fe}$ & $\mathrm{Zn}$ & Mn & $\mathrm{Ca}$ & $\mathbf{K}$ & Mg & $\mathrm{Na}$ & Vit. C \\
\hline \multirow{8}{*}{ Banana } & NLBA & $0.018 \pm 0.003$ & $1.58 \pm 0.036$ & $0.84 \pm 0.045$ & $5.55 \pm 0.110$ & $30.95 \pm 0.790$ & $1349 \pm 12.53$ & $111.8 \pm 1.51$ & $0.059 \pm 0.001$ & $9.12 \pm 0.52$ \\
\hline & NEBA & $0.066 \pm 0.007$ & $4.24 \pm 0.455$ & $1.38 \pm 0.01$ & $3.60 \pm 0.21$ & $43.67 \pm 3.21$ & $1259 \pm 12$ & $111 \pm 43$ & $0.063 \pm 0.002$ & $17.9 \pm 2.22$ \\
\hline & VV BA & $0.020 \pm 0.001$ & $1.5 \pm 0.15$ & $0.75 \pm 0.09$ & $6.55 \pm 0.49$ & $28.54 \pm 4.05$ & $1251 \pm 136$ & $100 \pm 11$ & $0.060 \pm 0.002$ & $4.12 \pm 0.48$ \\
\hline & ED BA1 & $0.143 \pm 0.017$ & $1.49 \pm 0.43$ & $0.74 \pm 0.09$ & $3.33 \pm 0.49$ & $48.44 \pm 5.74$ & $1070 \pm 113$ & $117 \pm 16$ & $0.079 \pm 0.003$ & $28.1 \pm 0.89$ \\
\hline & ED BA2 & $0.010 \pm 0.008$ & $4.12 \pm 0.25$ & $1.16 \pm 0.01$ & $5.87 \pm 0.01$ & $90.29 \pm 0.59$ & $1116 \pm 22$ & $156 \pm 12$ & $0.047 \pm 0.002$ & $9.75 \pm 0.52$ \\
\hline & MT BA & $0.021 \pm 0.001$ & $1.04 \pm 0.04$ & $0.22 \pm 0.02$ & $0.18 \pm 0.02$ & $30.58 \pm 2.16$ & $173 \pm 18$ & $37.0 \pm 3.0$ & $0.244 \pm 0.108$ & $15.6 \pm 1.81$ \\
\hline & TN BA & $0.021 \pm 0.002$ & $1.16 \pm 0.01$ & $0.18 \pm 0.01$ & $0.66 \pm 0.01$ & $38.29 \pm 1.64$ & $258 \pm 25$ & $38.8 \pm 0.2$ & $1.88 \pm 0.21$ & $9.16 \pm 0.52$ \\
\hline & VN BA & $0.927 \pm 0.002$ & $3.28 \pm 0.55$ & $0.40 \pm 0.02$ & $2.92 \pm 0.69$ & $121 \pm 16$ & $733 \pm 60$ & $114 \pm 10$ & $2.96 \pm 0.14$ & $11.4 \pm 0.89$ \\
\hline \multirow{7}{*}{ Passion frui } & VN M1 & $0.104 \pm 0.013$ & $27.87 \pm 0.81$ & $1.75 \pm 0.02$ & $1.62 \pm 0.03$ & $248 \pm 10$ & $1273 \pm 21$ & $132 \pm 2$ & $197 \pm 1$ & $20.1 \pm 0.81$ \\
\hline & VN M2 & $0.021 \pm 0.001$ & $5.06 \pm 0.21$ & $0.25 \pm 0.05$ & $0.22 \pm 0.01$ & $121 \pm 9$ & $320 \pm 16$ & $51.3 \pm 3$ & $90.1 \pm 6.1$ & $18.5 \pm 0.77$ \\
\hline & NL M & $0.141 \pm 0.010$ & $13.4 \pm 0.76$ & $1.83 \pm 0.02$ & $0.88 \pm 0.01$ & $170 \pm 11$ & $1202 \pm 42$ & $111 \pm 10$ & $101 \pm 4$ & $15.7 \pm 1.01$ \\
\hline & NE M & $0.020 \pm 0.001$ & $9.01 \pm 0.16$ & $1.23 \pm 0.06$ & $1.51 \pm 0.01$ & $243 \pm 16$ & $1565 \pm 31$ & $123 \pm 13$ & $119 \pm 2$ & $22.1 \pm 0.89$ \\
\hline & TN M & $0.021 \pm 0.001$ & $3.22 \pm 0.40$ & $0.21 \pm 0.01$ & $0.23 \pm 0.02$ & $111 \pm 8$ & $354 \pm 19$ & $50.6 \pm 3.5$ & $92 \pm 7$ & $27.4 \pm 0.52$ \\
\hline & ED M1 & $0.018 \pm 0.007$ & $10.44 \pm 0.30$ & $1.16 \pm 0.04$ & $1.58 \pm 0.03$ & $227 \pm 13$ & $1465 \pm 23$ & $126 \pm 8$ & $116 \pm 2$ & $29.3 \pm 1.33$ \\
\hline & ED M2 & $0.111 \pm 0.011$ & $15.86 \pm 0.20$ & $1.47 \pm 0.02$ & $2.94 \pm 0.02$ & $245 \pm 9$ & $1290 \pm 18$ & $124 \pm 8$ & $136 \pm 2$ & $26.7 \pm 0.52$ \\
\hline \multirow{6}{*}{ Grape } & VB U & $9.94 \pm 0.27$ & $9.28 \pm 0.31$ & $1.09 \pm 0.09$ & $1.62 \pm 0.07$ & $231 \pm 11$ & $1005 \pm 24$ & $93 \pm 2$ & $0.063 \pm 0.001$ & $17.3 \pm 0.52$ \\
\hline & ST U & $0.311 \pm 0.01$ & $0.79 \pm 0.62$ & $0.14 \pm 0.02$ & $0.67 \pm 0.08$ & $53.29 \pm 9.20$ & $232 \pm 74$ & $35.8 \pm 1.3$ & $0.516 \pm 0.004$ & $23.6 \pm 1.01$ \\
\hline & VV U1 & $0.155 \pm 0.02$ & $0.58 \pm 0.09$ & $0.081 \pm 0.001$ & $0.11 \pm 0.01$ & $50.4 \pm 7.0$ & $138 \pm 12$ & $20.8 \pm 2.9$ & $0.194 \pm 0.019$ & $15.4 \pm 0.98$ \\
\hline & VV U2 & $0.237 \pm 0.110$ & $0.88 \pm 0.42$ & $0.11 \pm 0.05$ & $0.19 \pm 0.09$ & $70.79 \pm 1.23$ & 211.27 & $29.1 \pm 1.3$ & $0.582 \pm 0.005$ & $2.95 \pm 0.52$ \\
\hline & VV U3 & $0.053 \pm 0.050$ & $0.33 \pm 0.03$ & $0.06 \pm 0.01$ & $0.051 \pm 0.003$ & $28 \pm 0.44$ & $84 \pm 4$ & $13.2 \pm 1.2$ & $0.023 \pm 0.001$ & $22.6 \pm 1.01$ \\
\hline & VN U & $1.46 \pm 0.09$ & $8.41 \pm 0.32$ & $0.97 \pm 0.01$ & $2.30 \pm 0.05$ & $352 \pm 25$ & $235 \pm 16$ & $105 \pm 14$ & $0.386 \pm 0.026$ & $12.6 \pm 0.52$ \\
\hline \multirow{9}{*}{ Eggplant } & ED BE & $0.681 \pm 0.002$ & $26.47 \pm 2.01$ & $6.04 \pm 0.018$ & $5.78 \pm 0.21$ & $367 \pm 5$ & $1441 \pm 26$ & $216 \pm 10$ & $101 \pm 4$ & $15.6 \pm 1.89$ \\
\hline & VV BE & $0.221 \pm 0.09$ & $3.53 \pm 0.03$ & $0.22 \pm 0.02$ & $0.22 \pm 0.01$ & $35.42 \pm 21$ & $360 \pm 11$ & $36.3 \pm 0.5$ & $0.37 \pm 0.07$ & $21.7 \pm 0.62$ \\
\hline & TN BE & $0.017 \pm 0.001$ & $0.050 \pm 0.001$ & $0.010 \pm 0.001$ & $0.320 \pm 0.020$ & $0.030 \pm 0.002$ & $3.38 \pm 0.30$ & $0.167 \pm 0.031$ & $8.75 \pm 0.09$ & $8.801 \pm 0.201$ \\
\hline & VN BE & $0.012 \pm 0.001$ & $0.49 \pm 0.08$ & $0.045 \pm 0.003$ & $\begin{array}{c}0.0502 \pm \\
0.002\end{array}$ & $10.48 \pm 0.39$ & $69.01 \pm 0.85$ & $13.3 \pm 0.27$ & $1.51 \pm 0.03$ & $18.5 \pm 0.44$ \\
\hline & FW BE & $0.048 \pm 0.004$ & $1.66 \pm 0.016$ & $0.064 \pm 0.013$ & $0.15 \pm 0.014$ & $27.22 \pm 0.26$ & $164 \pm 10$ & $31.6 \pm 0.54$ & $1.12 \pm 0.17$ & $70.4 \pm 0.89$ \\
\hline & NL BE & $0.926 \pm 0.001$ & $19.93 \pm 2.65$ & $2.13 \pm 0.04$ & $2.16 \pm 0.03$ & $141 \pm 2$ & $1591 \pm 21$ & $161 \pm 2$ & $3.1 \pm 0.08$ & $21.4 \pm 0.33$ \\
\hline & VB BE & $0.528 \pm 0.002$ & $9.32 \pm 0.02$ & $2.08 \pm 0.11$ & $1.10 \pm 0.01$ & $130 \pm 11$ & $1666 \pm 39$ & $163 \pm 6$ & $96.65 \pm 1.44$ & $37.6 \pm 1.01$ \\
\hline & NO BE & $0.545 \pm 0.003$ & $19.2 \pm 0.50$ & $5.72 \pm 0.53$ & $4.33 \pm 0.22$ & $93.61 \pm 4.05$ & $1185 \pm 38$ & $204 \pm 7$ & $32.90 \pm 10$ & $18.5 \pm 0.85$ \\
\hline & NE BE & $0.105 \pm 0.001$ & $7.87 \pm 0.63$ & $0.75 \pm 0.04$ & $0.52 \pm 0.03$ & $26.48 \pm 2.25$ & $418 \pm 13$ & $41.6 \pm 1.7$ & $20.74 \pm 0.33$ & $32.6 \pm 0.89$ \\
\hline
\end{tabular}

* $s d$ : standard deviation, $\mathrm{n}$ : number of replicates $(\mathrm{n}=3)$

Table 1: Average contents $\left(\mathrm{mg} / 100 \mathrm{~g} \pm s d^{*}\right)$ of minerals and vitamin $\mathrm{C}$ in flour

\begin{tabular}{|c|c|c|}
\hline Minerals & NIST & Found \\
\hline $\mathbf{C a}$ & $5.05 \pm 0.09$ & $4.99 \pm 0.07$ \\
\hline $\mathbf{K}$ & $2.70 \pm 0.05$ & $2.76 \pm 0.07$ \\
\hline $\mathbf{M g}$ & 1.20 & $1.08 \pm 0.02$ \\
\hline $\mathbf{N a}$ & $136 \pm 4$ & $157 \pm 2$ \\
\hline $\mathbf{P}$ & $0.216 \pm 0.004$ & $0.217 \pm 0.006$ \\
\hline $\mathbf{F e}$ & $4.7 \pm 0.14$ & $4.8 \pm 0.12$ \\
\hline $\mathbf{M n}$ & $368 \pm 7$ & $369 \pm 4$ \\
\hline $\mathbf{Z n}$ & $246 \pm 8$ & $255 \pm 9$ \\
\hline
\end{tabular}

Table 2: Results of Certified Reference Material (SRM) NIST 1573a

to the variability of the samples fruit flour on PC2. Vitamin C and $\mathrm{Na}$ are negatively correlated with $\mathrm{Mn}$.

In Figure 2 shows the graph of scores, on PC1 no grouping among the samples was checked.

On PC2 was verified a trend in the separation between the samples of fruit flour. Passion fruit flour samples are shifted to the region of positive scores, while samples of banana flour are displaced to the region of negative scores. Comparing with the graph of the weights, it can be observed that, passion fruit flour samples have the largest concentrations of Vitamin $\mathrm{C}$ and $\mathrm{Na}$ and lower concentrations of Mn. Banana flour samples have the largest concentrations of $\mathrm{Mn}$ and lower concentrations of $\mathrm{Na}$ and Vitamin $\mathrm{C}$. While that, the samples of flours of eggplant and grape no cluster was verified.

\section{Histochemical and microscopic analyzes}

Histochemical tests were performed to highlight some plant substances and thus recognize some peculiar aspects of chemical and morphological constitution of the fruits that form the flour. It was used 
Citation: Santos AMPD, Carvalho RDS, Vale AED, Lima JS, Santos IF, et al. (2014) Microscopic and Chemical Characterization of Flour of Fruits: An Alternative Source for Supplemental Feeding. J Food Process Technol 5: 386. doi:10.4172/2157-7110.1000386

Page 4 of 6

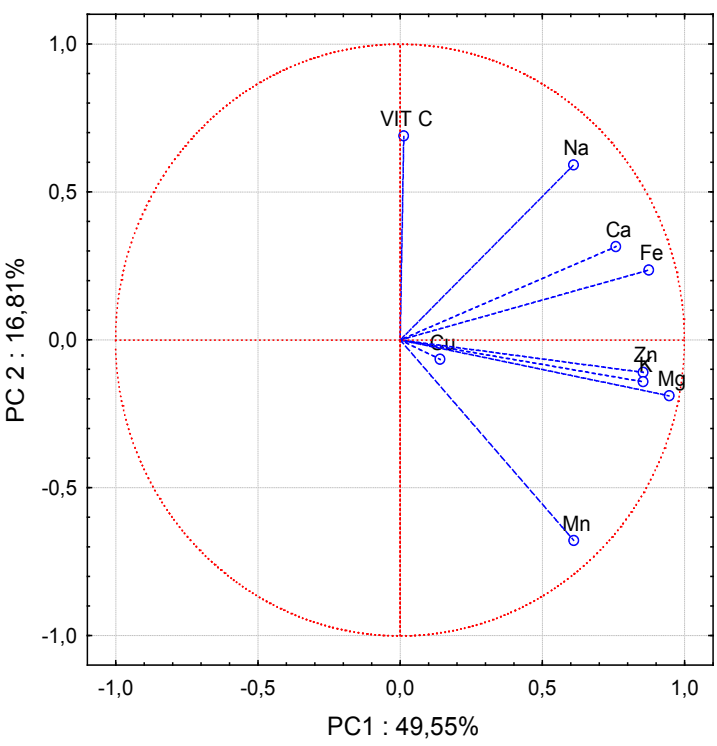

Figure 1: Graphic of loadings PC1×PC2 for fruit flour samples.

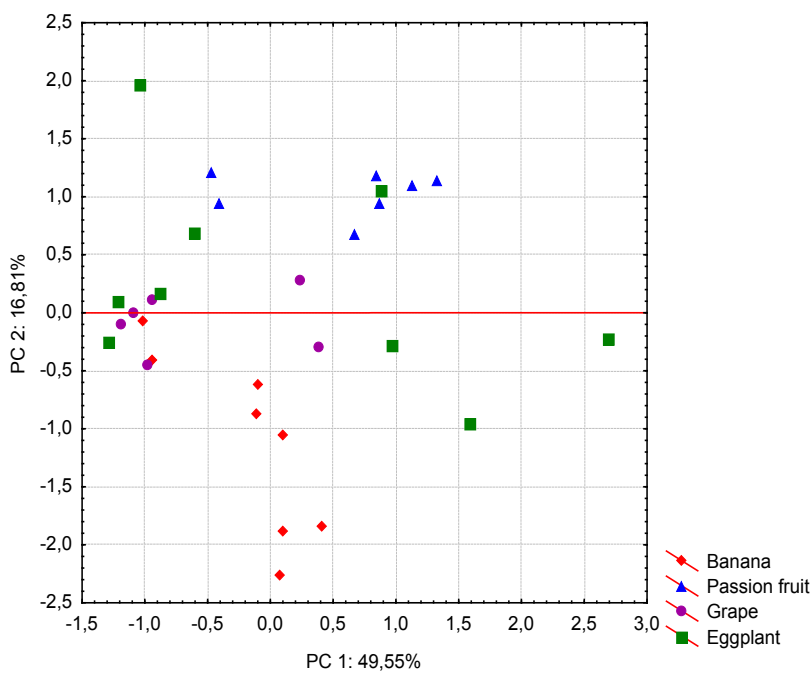

Figure 2: Scores plot of PC1×PC2 for fruit flour samples.

phloroglucinol with the addition of concentrated hydrochloric acid for evidencing lignified elements; Sudan III to the location of lipophilic substances; ferric chloride to determine the occurrence of phenolic compounds and lugol for detecting starch assimilation (Table 3).

In banana flour (Musa paradisiaca) was evidenced as a main component, the starch, by the formation of typical purplish colouration of the grains with the use of Lugol. The starch grains observed showed variation in morphology, size and grouping. Triangular, oval and elongated shapes that narrowed to the one end and had predominantly heterogeneous sizes (Figure 3). Were visualized the growth rings (lamellae) concentric from eccentric hilum and sometimes central. The eggplant flour (Solanum melongena) starch grains have been found in two distinct sizes, and almost without intermediate forms: small grains were rounded and large grains were lenticulars and ovals, having some distinct concentric layers. The hilum had form of a central point or a single line (Figure 4). This description suggests the addition of wheat starch (Triticum aestivum) to the composition also considering the lack of reports on the presence of starch in the proportion found in the eggplant flour. This finding is of particular concern because the high concentration of insoluble fiber characteristic eggplant justifies their use in reducing body weight and its adulteration with starch would lead to the opposite effect [15]. Microscopical analysis of eggplant flour, rounded cells from epicarp were strongly compressed and showed a purple coloration typical of eggplant anthocyanins (Figure 5). Much of the material was consisted of fragments of a spongy structure with cells and intercellular spaces own of the eggplant pulp [16]. In passion fruit flour (Passiflora spp) were observed mostly large cells of the pericarp,

\begin{tabular}{|l|c|c|c|c|c|c|}
\hline & Reagente & Banana & Eggplant & Passion fruit & Grape & Result \\
\hline Starch & Lugol & \pm & \pm & - & - & purplish \\
\hline $\begin{array}{l}\text { Lipophilics } \\
\text { compounds }\end{array}$ & Sudan III & - & \pm & \pm & - & red \\
\hline $\begin{array}{l}\text { Phenolics } \\
\text { compounds }\end{array}$ & $\mathrm{FeCl}_{3}$ & \pm & \pm & \pm & \pm & brown \\
\hline Lignin & Phloroglucinol & \pm & \pm & \pm & \pm & red \\
\hline
\end{tabular}

Table 3: Histochemical tests for detection of plant substance
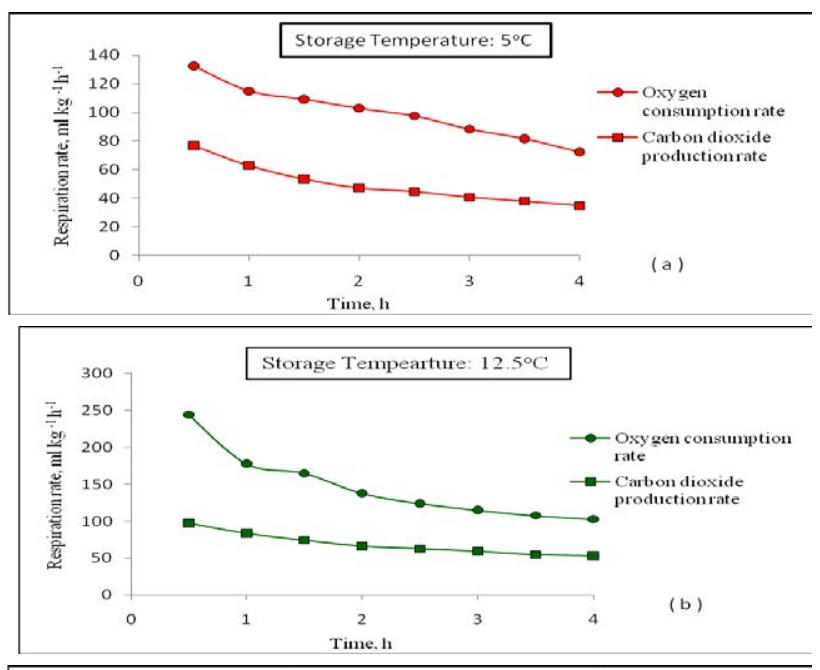

Figure 3: Starch grains of banana flour (40x)

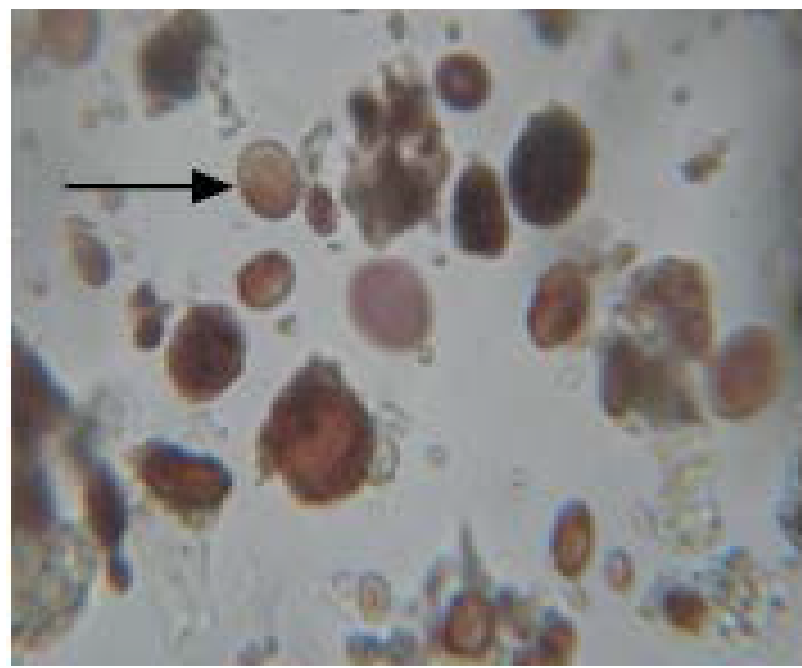

Figure 4: Starch grains of wheat found in the flour of the eggplant (40x) 
Citation: Santos AMPD, Carvalho RDS, Vale AED, Lima JS, Santos IF, et al. (2014) Microscopic and Chemical Characterization of Flour of Fruits: An Alternative Source for Supplemental Feeding. J Food Process Technol 5: 386. doi:10.4172/2157-7110.1000386

Page 5 of 6

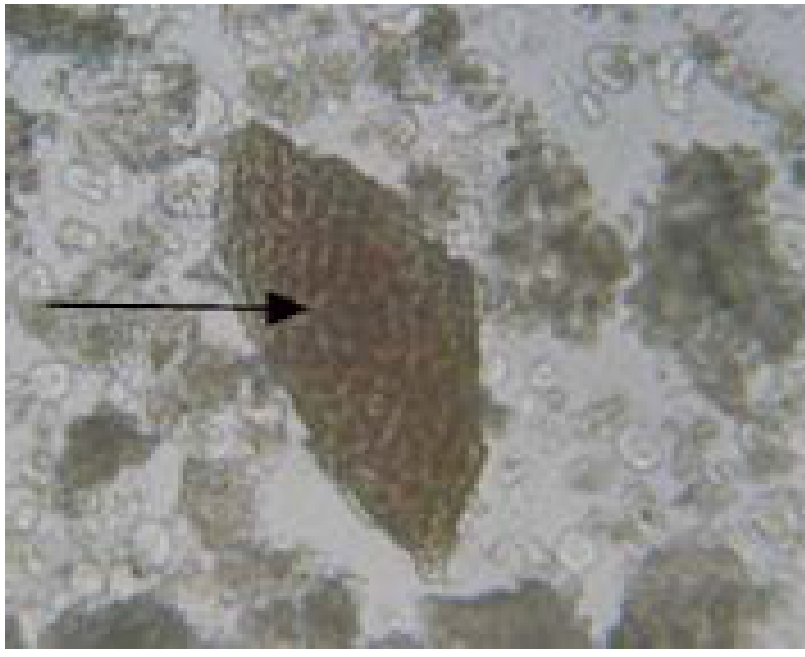

Figure 5: Flour with epicarp of eggplant (40x)

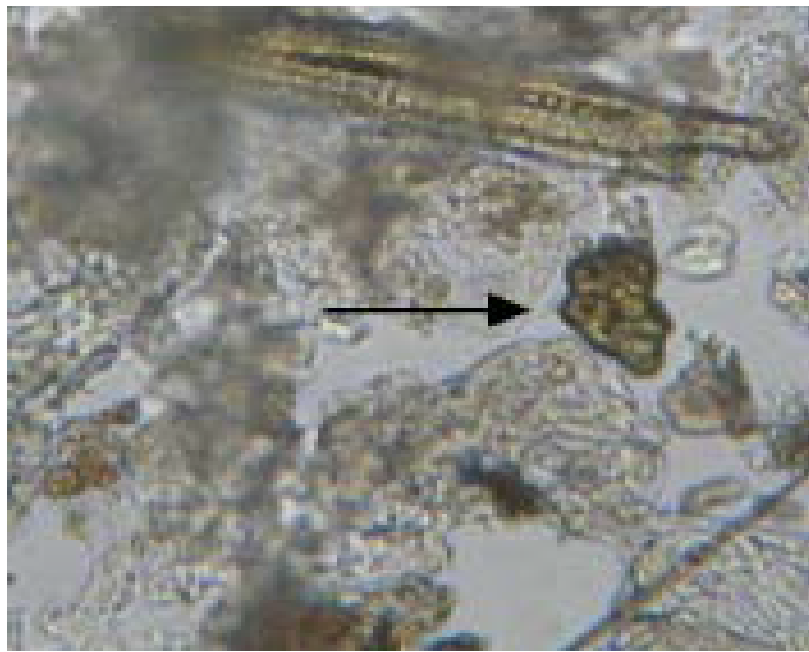

Figure 6: Flour with passion fruit epicarp (10x)

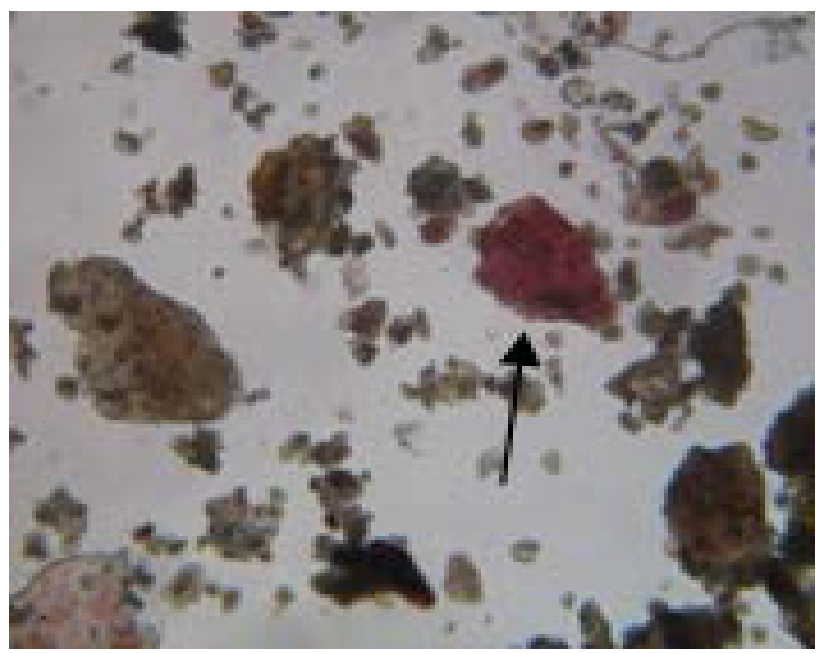

Figure 7: Flour with grape epidermis (10x) with some crystals in the form of drusen isolated and also fibers, in groups or isolated (Figure 6). The epicarp yellow coloration was seen in a few fragments of polygonal cells with rounded thickened rare stomata. Fragments of mesocarp at different depths were present in abundance. In the analysis of grapes flour (Vitis vinifera), the epicarp cells with thick walls slightly sinuous distinctly covered by the cuticle and the colenquimatosas cells appeared in pigmented fragments characteristic of anthocyanin from grapes (Figure 7). The epicarp showed overall look uniform with the wax layer of the reticular striated appearance. Cells of the mesocarp (edible pulp) showed rounded turgid with intercellular spaces evident [17-20].

Despite the technological processing that leads to extensive fragmentation, microscopic analysis shows that it is possible the visualization and identification of histological structures characteristics of fruit used in the preparation of flour.

\section{Conclusions}

It was possible to determine macro $(\mathrm{K}, \mathrm{Ca}, \mathrm{Na}, \mathrm{Mg})$ and micronutrients $(\mathrm{Cu}, \mathrm{Fe}, \mathrm{Mn}$ and $\mathrm{Zn})$ satisfactorily in the thirty flour samples of four varieties. PCA demonstrated that, the variables Vitamin $\mathrm{C}$ and $\mathrm{Na}$ are negatively correlated with $\mathrm{Mn}$. Passion flour samples have the largest concentrations of Vitamin $\mathrm{C}$ and $\mathrm{Na}$ and lower concentrations of $\mathrm{Mn}$. Banana flour samples have the largest concentrations of $\mathrm{Mn}$ and lower concentrations of $\mathrm{Na}$ and Vitamin $\mathrm{C}$. No tendency towards separation of flour eggplant and grape samples was observed in PCA.

Microscopic analysis allowed the visualization of tissues, epidermis, own fruit pulps from constituents in flour and determination of substances odd to its composition. We emphasize the need to control the marketing of these products, when in some samples studied adulteration was detected. Other parameters such as stability, microbiological contamination, humidity and other strange components should be determined to establish the best conditions for food use.

\section{Acknowledgements}

The authors are grateful to Brazilian agencies PRONEX/Fundacão de Amparo à Pesquisa do Estado da Bahia (FAPESB), Conselho Nacional de Desenvolvimento Científico e Tecnológico (CNPq) and Coordenacão de Aperfeiçoamento de Pessoal de Nível Superior (CAPES) for grants and fellowships.

\section{References}

1. Brasil. Agência Nacional de Vigilância Sanitária (2005) Resolução RDC n² 263 de 22 de setembro de 2005. Aprova o regulamento técnico para produtos de cereais, amidos, farinhas e farelos. Diário Oficial da União. Brasília1: 368-369.

2. United Nations System Standing Committee on Nutrition (2010) 6th Report on the World Nutrition Situation: Progress in Nutrition. Geneva, Switzerland.

3. United Nations, Food and Agriculture Organization- FAO (2009) 1.02 Billion People Hungry: One Sixth of Humanity Undernourished -More than ever before.

4. Mohammed Zafar IM, Bhatawale SP, Mehrajfatema ZM, Mirza RS, Mohammad UI, et al. (2012) Effect of Unripe Banana Flour Incorporation in Rice Papad and Resistance Starch Content. J Food Process Technol 3: 169.

5. Kadam ML, Salve RV, Mehrajfatema ZM, More SG (2012) Development and Evaluation of Composite Flour for Missi roti /chapatti. J Food Process Technol 3: 134.

6. Srivastava S, Genitha TR, Yadav V (2012) Preparation and Quality Evaluation of Flour and Biscuit from Sweet Potato. J Food Process Technol 3: 1-5.

7. Guimarães RR, Freitas MCJ, Silva VLM (2010) Bolos simples elaborados com farinha da entrecasca de melancia (Citrullus vulgaris, sobral): avaliação química, fisica e sensorial. Ciênc. Tecnol. Aliment 30: 354-363.

8. Grusak MA, DellaPenna D (1999) Improving the nutrient composition of plants 
Citation: Santos AMPD, Carvalho RDS, Vale AED, Lima JS, Santos IF, et al. (2014) Microscopic and Chemical Characterization of Flour of Fruits: An Alternative Source for Supplemental Feeding. J Food Process Technol 5: 386. doi:10.4172/2157-7110.1000386

to enhance human nutrition and health. Annu Rev Plant Physiol Plant Mol Biol 50: 133-161.

9. Anunciacao DS, Leao DJ, Jesus RM, Ferreira SLC (2011) Use of multivariate analysis techniques for evaluation of analytical data-determination of the mineral composition of cabbage (Brassica oleracea). Food Anal Methods 4: 286-292.

10. Santos I, Santos A, Barbosa U, Lima J, Matos G (2013) Multivariate analysis of the material content of raw and cooked (Abelmoschus Esculentus L). Microchem J 110: 439-443.

11. Sarathathev S, Ravindran G (1993) Physical Plant Foods for Human Nutritionand biochemical properties of green banana flour. Plant Foods Hum Nutr 43: 19-27.

12. Menezes EW, Tadini CC, Tribess TB, Zuleta A, Binaghi J, et al. (2011) Chemical Composition and Nutritional Value of Unripe Banana Flour (Musa acuminata, var. Nanicão). Plant Foods Hum Nutr 66: 231-237.

13. Miller JN, Miller JC (2000) Statistic and Chemometrics for analytical Chemistry Pearson Education, England.

14. Camelo MGA Ragazzo-Sánchez JA, Jiménez-Aparicio AR, Vanegas-Espinoza PE, Paredes-López O, et al. (2013) Comparative Study of Anthocyanin and
Volatile Compounds Content of Four Varieties of Mexican Roselle (Hibiscus sabdariffa L.) by Multivariable Analysis. Plant Foods Hum Nutr 68: 229-234.

15. AOAC (Association of Official Analytical Chemists) (2000) Official methods of analysis. 17. ed. Gaithersburg, MD.

16. Andréia B de Oliveira, Maria $S$ de Mendonça, Aristea A Azevedo, Renata MSA Meira (2012) Anatomy and histochemistry of the vegetative organs of Cissus verticillata - anative medicinal plant of the Brazilian Amazon. Braz $J$ Pharmacogn 22: 1201-1211.

17. Núcleo de Estudos e Pesquisas em Alimentação, Universidade Estadual de Campinas (2011) Tabela Brasileira de Composição de Alimentos - TACO Gráfica BookEditora, Campinas.

18. Santos KA, Karam LM, Freitas RJS, Stertz SC (2002) Composição química da berinjela (Solanum melongena L.). B.CEPPA 20: 247-256

19. Puig A, Perez MI, Carcel JA, Hernando I, Garcia-Perez JV (2012) Moisture loss kinetics and microstructural changes in eggplant (Solanum melongena L.) during conventional and ultrasonically assisted convective drying. Food Bioprod Process 90: 624-632.

20. Fava J, Hodara K, Nieto A, Guerrero S, Alzamora SM, et al. (2011) Structure (micro, ultra, nano), color and mechanical properties of Vitis labrusca L. (grape berry) fruits treated by hydrogen peroxide, UV-C irradiation and ultrasound Food Res Int 44: 2938-2948. 